\title{
Thermal dehydration kinetics of phosphogypsum
}

\author{
F.A. López®, H. Tayibi, I. García-Díaz, F.J. Alguacil \\ Centro Nacional de Investigaciones Metalúrgicas (CENIM-CSIC) (Madrid, Spain) \\ $\triangle$ flopez@cenim.csic.es
}

\begin{abstract}
Received 15 October 2014
Accepted 30 January 2015 Available on line $24 \mathrm{~J}$ une 2015
\end{abstract}

\begin{abstract}
Phsophogypsum is a by-product from the processing phosphate rock. Before the use of it in cement industry such as setting regulator is necessary a study of dehydration reaction of phosphogypsum to avoid the false setting during the milling.

The aim is to study the thermal behavior of two different phosphogypsum sources (Spain and Tunisia) under non-isothermal conditions in argon atmosphere by using Thermo-Gravimetriy, Differential Thermal Analysis (TG-DTA) and Differential Scanning Calorimetry (DSC).

DSC experiments were carried out at temperatures ranging from ambient to $350{ }^{\circ} \mathrm{C}$ at different heating rates. The temperatures of conversion from gypsum to hemihydrate and anhydrite states and heat of dehydration were determined. Various methods were used to analyze the DSC data for reaction kinetics determination. The activation energy and frequency factor were calculated for dehydration of phosphogypsum. Activation energy values of the main dehydration reaction of phosphogypsum were calculated to be approximately $61-118 \mathrm{~kJ} / \mathrm{mol}$.
\end{abstract}

KEYWORDS: Phosphogypsum; Kinetics; Dehydration; Thermal behavior; Cement

Citation/Citar como: López, F.A.; Tayibi, H.; García-Díaz, I.; Alguacil, F.J. (2015) Thermal dehydration kinetics of phosphogypsum. Mater. Construcc. 65 [319], e061. http://dx.doi.org/10.3989/mc.2015.07214.

RESUMEN: Estudio cinético de la deshidratación térmica del fosfoyeso. El fosfoyeso es un subproducto procedente del procesado de la roca fosfato. Una de las posibles vías de reutilización y revalorización es su uso como regulador del fraguado en la industria cementera. Debido a los posibles problemas de falso fraguado asociado a los procesos de deshidratación que tienen lugar durante la molienda del cemento, esta investigación estudió el comportamiento térmico, bajo condiciones no-isotérmicas en atmósfera de argón, de dos fosfoyesos, mediante TG-DTA y DSC.

Los ensayos de DSC se realizaron hasta $\operatorname{los} 350^{\circ} \mathrm{C}$ a diferentes velocidades de calentamiento. La temperatura de conversión del yeso a las formas de hemihidrato y anhidrita y el calor de hidratación fueron determinados.

Las cinéticas de reacción fueron obtenidas analizando los datos de DSC mediante varios métodos. Se calculó la energía de activación y el factor de frecuencia para las reacciones de deshidratación del subproducto. Los valores de energía de activación de las principales reacciones de deshidratación del fosfoyeso fueron obtenidos, aproximadamente $61-118 \mathrm{~kJ} / \mathrm{mol}$.

PALABRAS ClAVE: Fosfoyeso; Cinética; Deshidratación; Comportamiento térmico; Cemento

Copyright: (C) 2015 CSIC. This is an open-access article distributed under the terms of the Creative Commons Attribution-Non Commercial (by-nc) Spain 3.0 License. 


\section{NOMENCLATURE}

\author{
$E=$ reaction activation energy $[\mathrm{kJ} / \mathrm{mol}]$ \\ $f(\alpha)=$ differential form of the reaction mechanism \\ function \\ $g(\alpha)=$ integral form of the reaction mechanism \\ function \\ $R=$ gas constant, $8.314\left[\mathrm{~J} \mathrm{~mol}^{-1} \mathrm{~K}^{-1}\right]$ \\ $A=$ pre-exponential factor $\left[\mathrm{s}^{-1}\right]$ \\ $T=$ temperature of the reaction $[\mathrm{K}]$ \\ $t=$ time $[\mathrm{s}]$ \\ Greek symbols \\ $\alpha=$ degree of advance of reaction (degree \\ of conversion) \\ $\beta=$ heating rate $\left[\mathrm{K} \mathrm{min}^{-1}\right]$ \\ Subscripts \\ $P G=$ phosphogypsum \\ $P G S=$ phosphogypsum-Spain \\ $P G T=$ phosphogypsum-Tunisia \\ $D_{50}=$ the size in microns that splits the distribution \\ with half above and half below this diameter.
}

\section{INTRODUCTION}

Phosphogypsum (PG) is a by-product from the processing phosphate rock by the wet process to obtain acid phosphoric according to Eq. [1]:

$$
\begin{gathered}
\mathrm{Ca}_{5}\left(\mathrm{PO}_{4}\right)_{3} \mathrm{~F}+5 \mathrm{H}_{2} \mathrm{SO}_{4}+10 \mathrm{H}_{2} \mathrm{O} \rightarrow \\
3 \mathrm{H}_{3} \mathrm{PO}_{4}+5 \mathrm{CaSO}_{4} \cdot 2 \mathrm{H}_{2} \mathrm{O}+\mathrm{HF}
\end{gathered}
$$

Phosphogypsum consists mainly of calcium sulfate dihydrate with small amount of silica, usually as quartz. Radium and uranium, as well as minor amounts of toxic metals, arsenic, barium, cadmium, chromium, lead, mercury, selenium and silver and phytotoxic fluoride and aluminum are also present in phosphogypsum and its pore water. The concentration of heavy metals and radionucleides depend on the composition of the phosphate rock feed $(1,2)$.

For every tone of phosphoric acid produced, about three tones of phosphogypsum are yield. A world PG production is around 200-280 $10^{6} \mathrm{t}$ per year (3). Only the $15 \%$ of this amount of byproduct has commercial uses, in agriculture and in manufacturing gypsum board and Portland cement (4). The remaining $85 \%$ is disposed of without any treatment in large stockpiles exposed to weathering processes, occupying considerable land areas and causing serious environmental damage (chemical and radioactive contamination), particularly in coastal areas. The US EPA, United States Environmental Protection Agency classified PG as a "Technologically Enhanced Naturally Occurring Radioactivite
Material", Thus the valorization and recycling of PG are being now very necessary (5).

Nowadays a number of researches are focused on finding new uses of PG: a) agricultural fertilizer or for soil stabilization amendments (6-8); b) cement industry as a setting regulator in place of natural gypsum $(4,9,10)$, in the gypsum industry to make gypsum plaster $(4,11,12)$, as mineralizer in the burning Portland cement clinker (PCC) (13), as raw material in the raw mix of cement (14-16) and in other binders materials (17-20).

The cement manufactures add between 3 and $6 \%$ gypsum depending on its purity to avoid flash (immediate) setting of cement, also affect strength development and volume stability in the cement (21-24). Gypsum is the most common cement setting retarder used in industry. Gypsum is mixtures of mainly calcium sulphate dihydrate, calcium sulphate hemydrate and calcium sulphate anhydrite, similar composition to phosphogypsum. A high hemihydrate content result in false setting of cement, thus a maximum percentage of hemydrate is requires in gypsum sample (25).

It is well know that during the industrial production of cement hydrated calcium sulfates undergo partial dehydration at $110-130^{\circ} \mathrm{C}$ in the cement mill forming hemihydrates $\mathrm{CaSO}_{4} 0.5 \mathrm{H}_{2} \mathrm{O}$ and in some cases the total dehydrated, at $170-190{ }^{\circ} \mathrm{C}$, forming anhydrite $\mathrm{CaSO}_{4}$ (26), so it is crucial to cement industry to know the temperature and the kinetic dehydration of different calcium sulphate forms to attempt to control the milling temperature and avoid the formation these damaging gypsum components during the industrial cement production.

So before to use phosphogypsum such as setting regulator it's necessary to study dehydration reaction of PG in the direction to avoid the false setting by the production of hemihydrate and anhydrite during the milling process. The temperature and the kinetic dehydration of hydrated calcium sulfate could be influenced by different parameter such as origin sample, chemical composition and crystalline structure, $(27,28)$.

In this research was study the kinetic characteristics of PG dehydration via differential scanning calorimetry (DSC) in argon atmosphere. The objective of this study is to elucidate the reaction mechanisms and reaction kinetics of the dehydration of $\mathrm{PG}$ in a solid-state reaction. A kinetic model was proposed.

\section{MATERIALS AND METHODS}

\subsection{Sample preparation and characterization}

The PG samples used in this work came from Fertiberia factory of Bahía of Huelva (Spain) in 2009, named PGS and from Chemical Group (GZT) factory of Gulf of Gabès (Sfax, Tunisia) in 2009, 
named PGT. In order to obtain a representative sample, the sampling was carried out in situ. $300 \mathrm{~kg}$ of each PG sample were mixed and homogenized in a mixer ENRICH, with $200 \mathrm{~kg}$ of capacity, then quartered successively up to obtain a representative sample of $1 \mathrm{~kg}$, being subject of our experiments. After filtration and drying at $50{ }^{\circ} \mathrm{C}$ during $48 \mathrm{~h}$, the chemical composition of $\mathrm{PG}$, obtained by conventional methods, is listed in Table 1. The particles size was obtained by means of laser particle size analyzer Malvern Mastersize 2000 apparatus.

The diffractograms of PG samples were obtained using a X-ray diffractometer (Philips X'Pert PRO MPD) with $\mathrm{K} \alpha \mathrm{Cu}$ radiation (40 mA current and $45 \mathrm{kV})$. The patterns of diffraction were obtained in a $2 \Theta$ scanning range from $5^{\circ}$ to $80^{\circ}$, with $0.0167^{\circ}$ and $0.6 \mathrm{~s}$ of scan step and time, respectively.

\subsection{Thermal behavior of $P G$ samples}

PG samples were subjected to differential thermal and thermogravimetric analysis (DTA and TGA) in an inert atmosphere (argon). Setaram Sensys Evolution 1500 DTA/TGA analyzer was used to measure and record the sample mass change with temperature over the course of the dehydration reaction. Thermogravimetric curves were obtained at heating rate of $10{ }^{\circ} \mathrm{C} / \mathrm{min}$ between ambient and $650{ }^{\circ} \mathrm{C}$ in argon atmosphere $(20 \mathrm{ml} / \mathrm{min})$ and the sample mass was between 45 and $50 \mathrm{mg}$.

\subsection{Kinetic study}

The kinetic study of the dehydration of PG was performer with Differential Scanning Calorimetry (DSC) analysis. DSC experiments were performed

TABLE 1. Chemical composition of phosphogypsum samples

\begin{tabular}{lcc}
\hline Content (wt. \%) & PGS & PGT \\
\hline $\mathrm{SO}_{3}$ & 50.3 & 44.7 \\
$\mathrm{CaO}$ & 34.8 & 30.1 \\
$\mathrm{SiO}_{2}$ & 2.4 & 1.4 \\
$\mathrm{Total}_{2} \mathrm{O}_{5}$ & 0.9 & 1.2 \\
$\mathrm{Al}_{2} \mathrm{O}_{3}$ & 0.4 & 0.1 \\
$\mathrm{Fe}_{2} \mathrm{O}_{3}$ & 0.2 & 0.09 \\
$\mathrm{Na}_{2} \mathrm{O}$ & 0.1 & 0.6 \\
$\mathrm{~K}_{2} \mathrm{O}$ & 0.03 & 0.01 \\
$\mathrm{MgO}$ & 0.04 & 0.02 \\
$\mathrm{Total} \mathrm{F}$ & 3.8 & 4.9 \\
$\mathrm{Total} \mathrm{Radionuclides} \mathrm{(Bq/kg)}$ & 2441 & 635 \\
LOI & 7.0 & 16.9 \\
\hline
\end{tabular}

${ }^{\mathrm{a}}$ Total content of radionuclides $\left({ }^{238} \mathrm{U},{ }^{234} \mathrm{U},{ }^{235} \mathrm{U},{ }^{226} \mathrm{Ra},{ }^{210} \mathrm{~Pb},{ }^{210} \mathrm{Po}\right.$, ${ }^{40} \mathrm{~K}$ and ${ }^{232} \mathrm{Th}$ ) (Tayibi et al. 2011) [3] on a Setaram Model mod 3D-EVO. Non-isothermal analysis was carried out at four different heating rates $\left(5,10,15\right.$, and $\left.20^{\circ} \mathrm{C} / \mathrm{min}\right)$ between ambient and $350^{\circ} \mathrm{C}$. Temperature calibration was achieved by using the ICTAC-recommended DSC standards. The precision of reported temperatures was estimated to be $\pm 2{ }^{\circ} \mathrm{C}$. Sample mass was about $60 \mathrm{mg}$ and was placed in a $175 \mu \mathrm{l} \mathrm{Al}$ crucible sealed. All the experiments were conducted in an inert atmosphere, argon with a flow rate of $20 \mathrm{ml} / \mathrm{min}$.

The reproducibility of the experiments is acceptable and the experiments data presented in this paper corresponding to the different operating conditions are the mean values of runs carried out two or three times.

\subsection{Theoretical consideration}

Generally for PG degradation, it is assumed that the rates of conversion are proportional to the concentration of reacted material. The rate of conversion can be expressed by the following basic rate equation [Eq. 2]:

$$
\frac{d \alpha}{d t}=\beta \frac{d \alpha}{d T}=k(T) . f(\alpha)
$$

Where $\alpha$ is the degree of conversion of reaction, $\mathrm{f}(\alpha)$ and $k(T)$ are functions of conversion and temperature. In the DSC experiments, the Eq. [2] can be expressed by the following Eq. [3]:

$$
\frac{d \alpha}{d t}=\frac{d H}{d t} \cdot \frac{1}{\Delta \text { Htotal }}
$$

Where $\frac{d H}{d t}$ is the heat flow above baseline and $\Delta$ Htotal the peak area of the reaction, expressed in $\mathrm{mJ}$.

By combining Eqs. [2] and [3], the rate of conversion can be written in form [4]:

$$
\frac{d \alpha}{d t}=\frac{d H}{d t} \cdot \frac{1}{\Delta H \text { total }}=k(T) \cdot f(\alpha)
$$

$k(T)$ the temperature dependence of the rate of heat flow, is often modelled successfully by the Arrhenius Eq. [5]:

$$
k(T)=A \exp \left(-\frac{E}{R T}\right)
$$

Where $E$ is the activation energy, A the pre-exponential factor and $\mathrm{R}$ is the gas constant.

By combining the Eqs. [4] and [5], the reaction rate can be written as follow [6]:

$$
\frac{d \alpha}{d t}=A \exp \left(-\frac{E}{R T}\right) \cdot f(\alpha)
$$




\subsubsection{Friedman method ( $F R$ )}

Friedman analysis (29), based on the Arrhenius equation, applies the logarithm of the conversion rate $\frac{d \alpha}{d t}$ as a function of the reciprocal temperature at different degrees of the conversion $\alpha$, according to Eq. [7]:

$$
\left.\ln \frac{d \alpha}{d t}\right|_{\alpha i}=\ln (A i f(\alpha i, j))-\frac{E i}{R \cdot T i, j}
$$

With $i$ is the index of conversion, $j$ is the index of the curve and $f\left(\alpha_{i, j}\right)$ the function dependent on the reaction model that is assumed to be constant for a given reaction progress $\alpha_{i, j}$ for all curves $j$. As $f(\alpha)$ is constant at each conversion degree $\alpha_{i}$, the dependence of the logarithm of the reaction rate over $\frac{1}{T}$ is linear with the slope of $\frac{E}{R \cdot T}$ and the intercept $A$.

\subsubsection{Flynn-Wall-Ozawa method ( FWO)}

The Flynn-Wall-Ozawa method $(30,31)$ is derived of integral isoconversional method. Using Doyle's approximation (32) for the integral which allows $\left(\ln p=\ln \left(\frac{E}{R T}\right) \approx-5.331-1.052 \frac{E}{R T}\right)$. The reaction rate in logarithmic form is [8]:

$$
\ln \beta=\ln \left(\frac{A E}{\operatorname{Rg}(\alpha)}\right)-5.331-1.052 \frac{E}{R} \frac{1}{T}
$$

Where $g(\alpha)$ is the integral function of conversion. Thus, for $\alpha=$ constant, the plot $\ln \beta$ vs. $\frac{1}{T}$, obtained from thermograms recorded at several heating rates, should be a straight line whose slope can be used to evaluate the activation energy.

\subsubsection{ASTM E698}

The analysis according to ASTM E698 (33) is based on the assumption that the maximum (for example maximum of the DSC curve) of a single step reaction is reached at the same conversion degree independently of the heating rate. Although this assumption is only partly right, the resulting error is small. In this method, the logarithm of the heating rate is plotted over the reciprocal temperature of the maximum. The slope of the yielded straight line is proportional to the activation energy, just as in the Ozawa-Flynn-Wall analysis [9]:

$$
\ln \left(\frac{\beta}{T}\right)=\ln A+\frac{E}{R} \frac{1}{T}+\ln (1-\alpha)
$$

\subsubsection{Coats-Redfern method}

Coats-Redfern method (34) is also an integrated method and it involves the thermal degradation mechanism. Using an asymptotic approximation for the resolution of integral Eq. [10] $(2 \mathrm{RT} / \mathrm{E}<1)$, the following Eq. [11] can be obtained:

$$
\begin{gathered}
g(\alpha)=\int_{0}^{\alpha} \frac{d \alpha}{f(\alpha)}=\frac{A}{\beta} \int_{T_{o}}^{T} \exp \left(-\frac{E}{R T}\right) d T=\frac{A E}{\beta R} p\left(\frac{E}{R T}\right) \\
\ln \frac{g(\alpha)}{T^{2}}=\ln \frac{A R}{\beta E}-\frac{E}{R T}
\end{gathered}
$$

The method by Coats-Redfern is one of the most widely used procedures for the determination of the reaction processes. From Eq. [11], proposed by Coats and Redfern, the activation energy for all $\mathrm{g}(\alpha)$ functions listed in Table 2 can be obtained at constant heating rate. Table 2 indicates the algebraic expressions of $f(\alpha)$ and $g(\alpha)$ for the used kinetic model.

\section{RESULTS AND DISCUSSIONS}

\subsection{Phosphogypsum Characterization}

Morphologically, both PG samples were yellowish brown color and relatively soft grains. The particle size of phosphogypsum were $\mathrm{D}_{50}=53 \mu \mathrm{m}$ and $\mathrm{D}_{50}=83 \mu \mathrm{m}$ for PGS and PGT, respectively. Chemically, the PG mainly consists of $\mathrm{SO}_{3}, \mathrm{CaO}$ with low contents of $\mathrm{SiO}_{2}, \mathrm{Fe}_{2} \mathrm{O}_{3}, \mathrm{Al}_{2} \mathrm{O}_{3}$ and $\mathrm{P}_{2} \mathrm{O}_{5}$ as well as traces of $\mathrm{Na}_{2} \mathrm{O}, \mathrm{K}_{2} \mathrm{O}, \mathrm{TiO}_{2}, \mathrm{~F}$ and $12-22 \%$ ignition loss (LOI). In addition to radionuclides such as ${ }^{226} \mathrm{Ra},{ }^{210} \mathrm{~Pb},{ }^{238} \mathrm{U}$ and ${ }^{40} \mathrm{~K}$, the chemical analysis of $\mathrm{PG}$ is reported in Table 1 .

Figure 1 reports the powder X-ray diffraction pattern of PG samples. As shown, PGS presents two maximum intensity diffraction peaks corresponding to calcium sulfate dihydrate $\left(\mathrm{CaSO}_{4} \cdot 2 \mathrm{H}_{2} \mathrm{O}\right)$ (JCPDS 74-1433), calcium sulfate hemihydrate $\left(\mathrm{CaSO}_{4} \cdot 0.5 \mathrm{H}_{2} \mathrm{O}\right)(\mathrm{JCPDS} 81-1848)$ and anhihidryte $\left(\mathrm{CaSO}_{4}\right)$ (JCPDS 37-1496). The semi-quantification of the phases by the magnitude of the diffraction line intensity shows the presence of approximately $64 \%$ of $\mathrm{CaSO}_{4} \cdot 2 \mathrm{H}_{2} \mathrm{O} ; 33 \% \mathrm{CaSO}_{4} \cdot 0.5 \mathrm{H}_{2} \mathrm{O}$ and $3 \%$ of $\mathrm{CaSO}_{4}$. These ratios are in accordance with the percentage of $\mathrm{S}$ and $\mathrm{Ca}$ obtained by the chemical analysis. The main diffraction peak of the PGT corresponds mainly to calcium sulfate dihydrate $\left(\mathrm{CaSO}_{4} \cdot 2 \mathrm{H}_{2} \mathrm{O}\right)$ (JCPDS 74-1433). The gypsum content in the PGT is $94 \%$, while the remainder is impurities.

The mineralogical composition of the PG depends strongly on its origin, the kind of acid phosphoric process used, environmental conditions of its storage and the age of the studied sample. Generally, PG could be composed by different ratios of three 
TABLE 2. Algebraic expressions of functions of the most common reaction mechanisms

\begin{tabular}{lll}
\hline Mechanism & \multicolumn{1}{c}{$\mathbf{f}(\alpha)$} & \multicolumn{1}{c}{$\mathbf{g}(\alpha)$} \\
\hline Autocatalytic & $(1-\alpha)^{\mathrm{n}} \cdot \alpha^{\mathrm{m}}$ & - \\
Avarani-Erofe've (A1.5) & $1.5(1-\alpha)[-\ln (1-\alpha)]^{1 / 3}$ & {$[-\ln (1-\alpha)]^{1 / 3}$} \\
Avarani-Erofe've (A2) & $2(1-\alpha)[-\ln (1-\alpha)]^{1 / 2}$ & {$[-\ln (1-\alpha)]^{1 / 2}$} \\
Avarani-Erofe've (An) & $\mathrm{n}(1-\alpha)[-\ln (1-\alpha)]^{(1-1 / \mathrm{n})}$ & {$[-\ln (1-\alpha)](1-1 / \mathrm{n})$} \\
First-order (F1) & $(1-\alpha)$ & $-\ln (1-\alpha)$ \\
Second-order (F2) & $(1-\alpha)^{2}$ & $(1-\alpha)-1-1$ \\
Third-order (F3) & $(1-\alpha)^{3}$ & {$[(1-\alpha)-2-1] / 2$} \\
Contracting sphere (R2) & $2(1-\alpha)^{1 / 2}$ & {$\left[1-(1-\alpha)^{1 / 2}\right]$} \\
Contracting Cylinder (R3) & $3(1-\alpha)^{2 / 3}$ & {$\left[1-(1-\alpha)^{1 / 3}\right]$} \\
Power law (P2) & $2 \alpha^{1 / 2}$ & $\alpha^{1 / 2}$ \\
Power law (P3) & $3 \alpha^{1 / 3}$ & $\alpha^{1 / 3}$ \\
Power law (P4) & $4 \alpha^{1 / 4}$ & $\alpha^{1 / 4}$ \\
One-dimensional diffusion (D1) & $1 / 2 \alpha$ & $\alpha^{2}$ \\
Two-dimensional diffusion (D2) & {$[-\ln (1-\alpha)]^{-1}$} & {$[(1-\alpha) \cdot \ln (1-\alpha)]+\alpha$} \\
Three-dimensional diffusion (D3) & $1.5\left[1-(1-\alpha)^{(1 / 3)}\right]^{-1}(1-\alpha)^{(2 / 3)}$ & {$\left[1-(1-\alpha)^{1 / 3}\right]^{2}$} \\
Giustling-Brounsthein (D4) & $1.5\left[(1-\alpha)^{(-1 / 3)}-1\right]^{-1}$ & $1-(2 \alpha / 3)-(1-\alpha)^{2 / 3}$ \\
\hline
\end{tabular}

mineralogical phases of calcium sulfate. For example, the presence of these three phases has been described by Ma et al. (2010) (35) in their study of the reaction mechanism and the kinetic of the decomposition through a solid state by means of reaction with carbon, of a PG from Yunnan Gas and Chemical Engineering Company. Strydom et al. (1999) (36) establish for a PG from Omma Fertiliser's plant in Rustenburg, ratios determined through XRD of $16 \%$ $\mathrm{CaSO}_{4} 2 \mathrm{H}_{2} \mathrm{O}, 66 \% \mathrm{CaSO}_{4} 0.5 \mathrm{H}_{2} \mathrm{O}$ and $15 \% \gamma-\mathrm{CaSO}_{4}$. López et al. (2011) (37), by studding a microencapsulation of a PG from Huelva Bay found only the

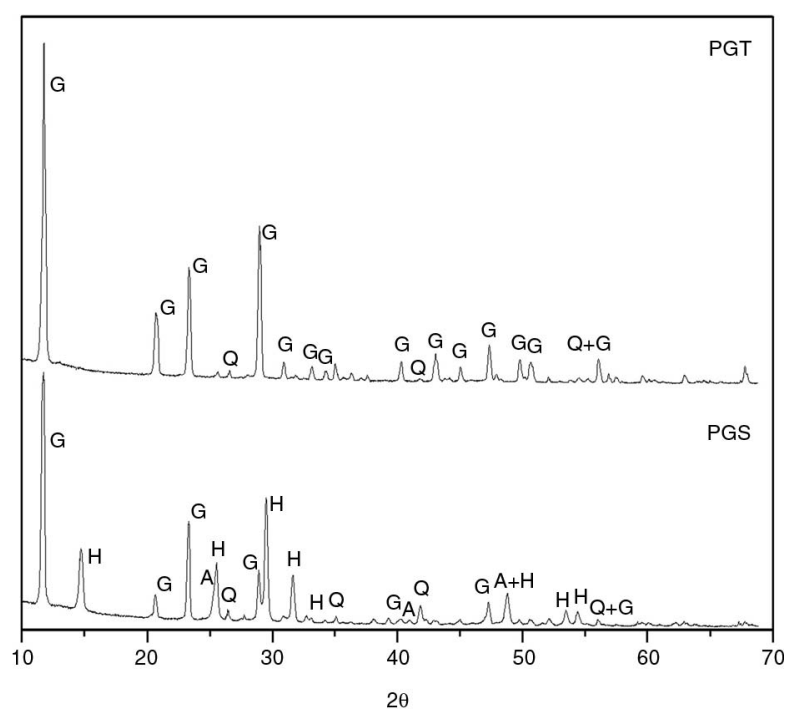

FIGURE 1. XRD difractograms of PGT and PGS samples. presence of the gypsum and the hemihydrate phases and carbon. Cárdenas-Escudero et al. (2011) (38) reported that for a PG from the same zone, only the dihydrated phase was found.

\subsection{Thermal behaviour of phosphogypsum}

Figure 2 shows the curves of TG, DTG and DTA obtained from heating the studied PG samples at $10{ }^{\circ} \mathrm{C} / \mathrm{min}$ in argon atmosphere and open crucible.

The curves show two consecutive and much closed endothermic peaks between $144^{\circ} \mathrm{C}$ and $175^{\circ} \mathrm{C}$ for PGS sample (Fig. 2a) and $156{ }^{\circ} \mathrm{C}$ and $191{ }^{\circ} \mathrm{C}$ for PGT sample (Fig. 2b). The proximity of both signals makes difficult the mass loss assignation, reported in the TG curves for each one of the effect area. In the studied temperature range, an exothermic peak appears at a maximum temperature of $433{ }^{\circ} \mathrm{C}$ in the PGS sample and $465^{\circ} \mathrm{C}$ in PGT sample. In the case of the exothermic peak, no mass loss was observed. The Table 3 reported the characteristic temperatures for each peak and its associated mass loss.

The first endothermic peak observed in the DTA/ DTG curves is attributed to the gypsum dehydration reaction and the formation of the hemihydrate, according to the Eq. [12]. The second peak corresponds to the transformation of hemihydrate to anhydrate, according to the Eq. [13]. At temperatures near $400{ }^{\circ} \mathrm{C}$, a slightly exothermic reaction occurs, in which the molecular structure of the soluble crystal (anhydrite III) irreversibly reorganizes itself into a lower insoluble energy state (anhydrite II or $\left.\beta-\mathrm{CaSO}_{4}\right)(39-41)$ [Eq. 14]. On the TG curve, no loss has been noticed at this temperature. 

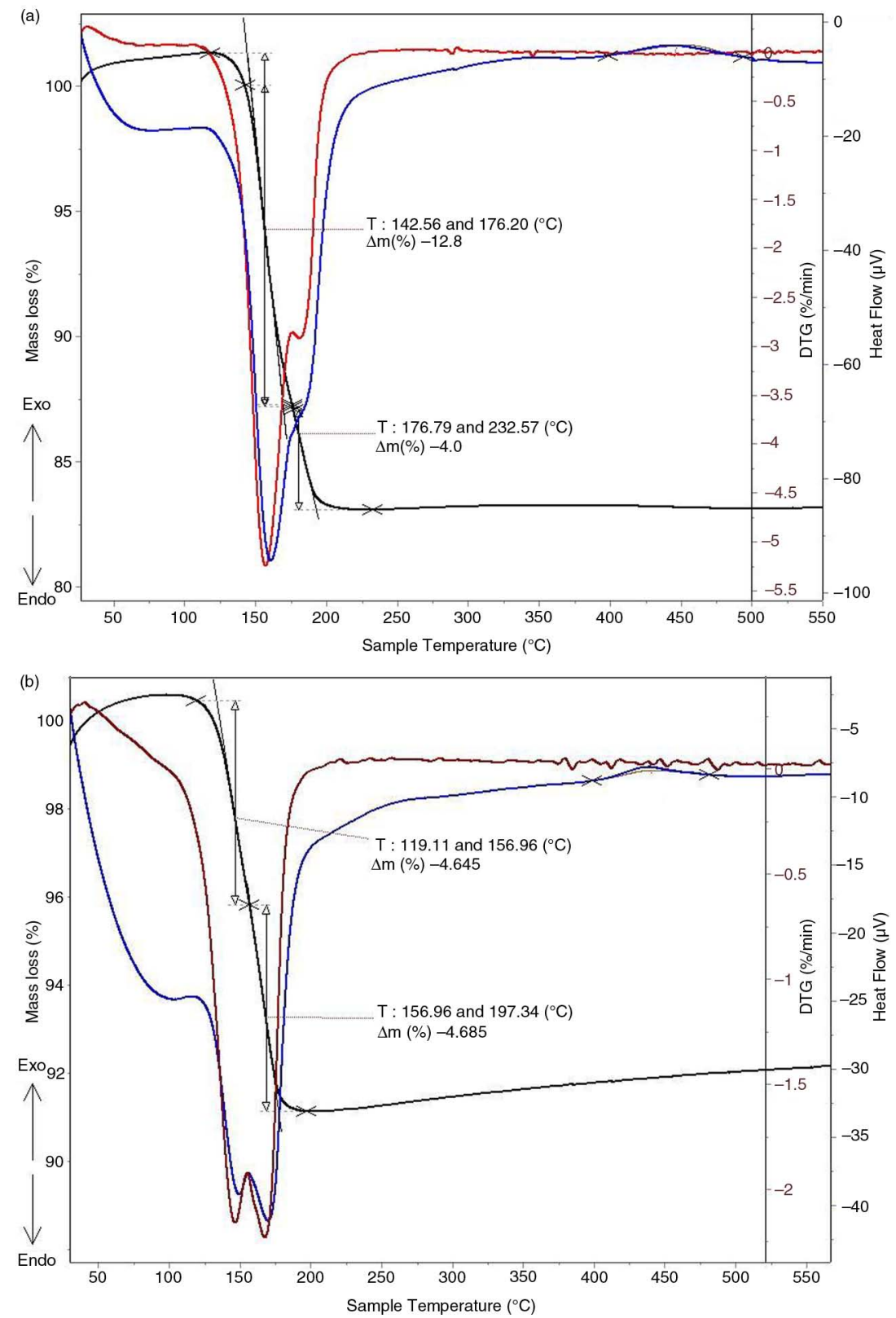

Figure 2. TG, DTG and DTA curves obtained by heating at $10^{\circ} \mathrm{C} / \mathrm{min}$ in inert atmosphere (argon): (a) PGS and (b) PGT samples.

TABLE 3. DTA and TGA results for thermal behavior of phosphogypsum

\begin{tabular}{|c|c|c|c|c|c|c|c|c|c|c|}
\hline \multirow[b]{3}{*}{ Peak } & \multicolumn{5}{|c|}{ PGS } & \multicolumn{5}{|c|}{ PGT } \\
\hline & \multicolumn{3}{|c|}{ DTA curve } & \multicolumn{2}{|c|}{ TG curve } & \multicolumn{2}{|c|}{ DTA curve } & \multicolumn{3}{|c|}{ TG curve } \\
\hline & To $\left({ }^{\circ} \mathrm{C}\right)$ & $\mathrm{Te}\left({ }^{\circ} \mathrm{C}\right)$ & $\operatorname{Tp}\left({ }^{\circ} \mathrm{C}\right)$ & $\begin{array}{c}\text { Interval } \\
\text { temperature }\left({ }^{\circ} \mathrm{C}\right) \\
\end{array}$ & $\begin{array}{c}\text { Mass loss } \\
\text { (wt, \%) }\end{array}$ & To $\left({ }^{\circ} \mathrm{C}\right)$ & $\mathrm{Te}\left({ }^{\circ} \mathrm{C}\right)$ & $\operatorname{Tp}\left({ }^{\circ} \mathrm{C}\right)$ & $\begin{array}{c}\text { Interval } \\
\text { temperature }\left({ }^{\circ} \mathrm{C}\right) \\
\end{array}$ & $\begin{array}{c}\text { Mass loss } \\
\text { (wt, \%) }\end{array}$ \\
\hline 1 & 133 & 155 & 144 & $119-157$ & 4.7 & 143 & 173 & 156 & $143-176$ & 12.8 \\
\hline 2 & 159 & 184 & 176 & $157-197$ & 4.7 & 176 & 201 & 191 & $176-233$ & 4.0 \\
\hline 3 & 423 & 453 & 433 & & 0 & 412 & 464 & 464 & & 0 \\
\hline $\begin{array}{l}\text { Total Mass Loss } \\
\left(40-650^{\circ} \mathrm{C}\right)\end{array}$ & - & - & - & - & 9.4 & & & - & - & 16.8 \\
\hline
\end{tabular}

$\left(\mathrm{T}_{\mathrm{o}}=\right.$ initial temperature, $\mathrm{T}_{\mathrm{e}}=$ final temperature and $\mathrm{T}_{\mathrm{p}}=$ maximum temperature peak $)$. 

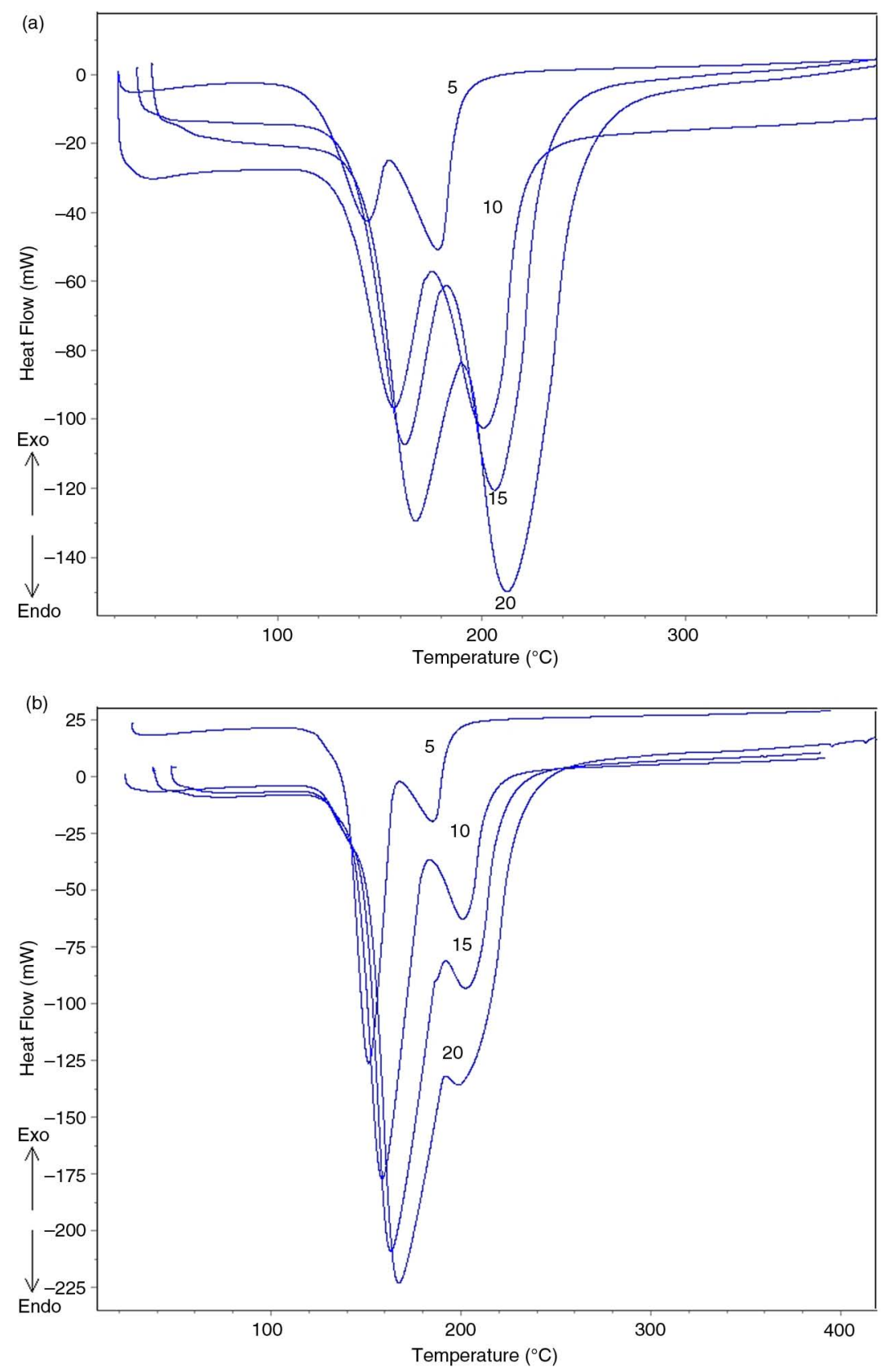

FIGURE 3. The DSC curves obtained during the thermal dehydration at different heating rates $\left(5,10,15\right.$ and $20^{\circ} \mathrm{C} / \mathrm{min}$ ) up to $350^{\circ} \mathrm{C}$ of the: (a) PGS sample and (b) PGT sample.

$$
\mathrm{CaSO}_{4} 2 \mathrm{H}_{2} \mathrm{O} \rightarrow \mathrm{CaSO}_{4} 0.5 \mathrm{H}_{2} \mathrm{O}+1.5 \mathrm{H}_{2} \mathrm{O}
$$

$$
\mathrm{CaSO}_{4} 0.5 \mathrm{H}_{2} \mathrm{O} \rightarrow \gamma-\mathrm{CaSO}_{4}\left(\text { or } \mathrm{CaSO}_{4} \mathrm{III}\right)+0.5 \mathrm{H}_{2} \mathrm{O}
$$

$$
\mathrm{CaSO}_{4} \mathrm{III} \rightarrow \mathrm{CaSO}_{4} \mathrm{II}
$$

The difference in DTG and DTA profiles, among two PG, indicates the influence of sample origin, chemical composition and traces on dehydration behavior (28). The most obvious discrepancy is the temperature, at which gypsum begins to dehydrate.
PGS begins to dehydrate at lowest temperature, while PGT dehydrate at highest temperature.

The TG curves analysis indicates that for the PGT sample, the mass loss observed between the ambient temperatures up to $500^{\circ} \mathrm{C}$ is $\approx 17 \mathrm{wt} \%$. This result is in accordance with the mass loss (LOI) obtained by the chemical analysis of the PG sample (Table 1), being the $12.8 \mathrm{wt} \%$ for the first peak and $4 \mathrm{wt} \%$ for the second one. Thus the mass loss is done according to a $3: 1$ rate. The two "jumps" of a 3:1 mass loss in TG curves are in accordance with 
the stoichiometry of the dehydration reactions: Eqs. [12] and [13].

For PGS sample, the total mass loss corresponding to the hydration reaction is $9.4 \mathrm{wt} \%$, being the $4.7 \mathrm{wt} \%$ for the first peak and $4.7 \mathrm{wt} \%$ for the second peak, which means a relation of $\approx 1: 1$. In this case, it should be noted that in the initial PGS sample coexist the dihydrate and hemihydrate phases, which explains the relation of the identified mass loss.

Most literature reported that gypsum dehydration undergoes a two-step process, via hemihydrate $(25,28,42-44)$, while some reports showed that $\gamma-\mathrm{CaSO}_{4}$ is directly produced during gypsum dehydration of $\gamma-\mathrm{CaSO}_{4}$ upon cooling with humidity air (45). Ball et al. (1969) (46) and Badens et al. (1998) (47) pointed out that both temperature and partial water pressure $\left(P_{\mathrm{H} 2 \mathrm{O}}\right)$ controlled the product of dehydration. Lou et al. (2011) (48) reported that under non-isothermal conditions and in two steps, via hemihydrate in "autogenous $\mathrm{P}_{\mathrm{H}_{2} \mathrm{O}}$ ", the dehydration of the gypsum contained in the "flue gas desulfurization gypsum (FGDG) occurs in one step $\left(\mathrm{CaSO}_{4} 2 \mathrm{H}_{2} \mathrm{O} \rightarrow \gamma-\mathrm{CaSO}_{4}\right)$, when the $\mathrm{P}_{\mathrm{H}_{2} \mathrm{O}}$ is negligible.

The dehydration behavior may vary significantly among different gypsum types, such as natural gypsum and many kinds of chemical gypsum. Differences in crystalline characteristics and impurities appear to be the most important factor resulting in discrepancies of dehydration behavior (27).

\subsection{Kinetics}

Figure 3 shows the DSC curves obtained during the thermal dehydration of both studied PG samples at different heating rates $(5,10,15$ and $20 \mathrm{~K} / \mathrm{min})$ up to $350^{\circ} \mathrm{C}$.
The $\mathrm{CaSO}_{4} 2 \mathrm{H}_{2} \mathrm{O}$ reaction dehydration takes place into steps according to two endothermic peaks. The first peak is observed (depending on the heating rate) at $\mathrm{T}_{\mathrm{p}}$ between 142 and $166^{\circ} \mathrm{C}$, for the PGS (Figure 3a) and between 151 and $163{ }^{\circ} \mathrm{C}$ for the PGT sample (Figure $3 \mathrm{~b}$ ). The second peak occurred at higher temperature, between 179 and $215^{\circ} \mathrm{C}$ for the PGS sample and 186 and $207^{\circ} \mathrm{C}$ for PGT sample. In both case and by increasing the heating rates, an increasing of the maximum of the degradation temperature is observed.

By considering the global dehydration reaction (step 1 and step 2), the Table 4 shows the maximums temperatures and the dehydration heat for each sample according to the heating rates. The dehydration heat was calculated from the integration of the area of the two endothermic peaks. The medium dehydration heats are $240.5 \mathrm{~J} / \mathrm{g}$ and $535.2 \mathrm{~J} / \mathrm{g}$ for the PGS and PGT samples, respectively, in accordance with the total mass loss (see section 3.2).

The results of the DSC curves obtained at different heating rates were used to calculate the activation energy of the dehydration reaction for the both PG samples. The activation energy was determined using Flynn-Wall-Ozawa (FWO), Friedman (FR) and ASTM E698 methods.

Firstly, the isoconversional Friedman method was used to calculate the activation energy for different conversion values. The plot of the variation of the $\ln \left(\frac{d \alpha}{d t}\right)$ in function of $1 / T$, for a constant $f(\alpha)$ at each conversion degree, $\alpha i$, straight lines were obtained for each $\alpha i$ value for the slope $(E / R)$, the activation energy value was obtained for each conversion degree $\alpha i$ (Figure 4).

The results of the activation energy for both PG samples are shown in Table 5 and 6 . The means values

TABLE 4. DSC results for the dehydration of phosphogypsum at different heating values

\begin{tabular}{|c|c|c|c|c|c|c|c|c|c|c|}
\hline PGS & \multicolumn{3}{|c|}{ Peak 1} & \multicolumn{3}{|c|}{ Peak 2} & \multicolumn{4}{|c|}{ Peak 1 and Peak 2} \\
\hline Heating Rate $\left({ }^{\circ} \mathrm{C} \min ^{-1}\right)$ & $\mathrm{T}_{0}\left({ }^{\circ} \mathrm{C}\right)$ & $\mathrm{T}_{\mathrm{e}}\left({ }^{\circ} \mathrm{C}\right)$ & $\mathbf{T}_{\mathrm{p}}\left({ }^{\circ} \mathrm{C}\right)$ & $\mathrm{T}_{\mathrm{o}}\left({ }^{\circ} \mathrm{C}\right)$ & $\mathrm{T}_{\mathrm{e}}\left({ }^{\circ} \mathrm{C}\right)$ & $\mathbf{T}_{\mathrm{p}}\left({ }^{\circ} \mathrm{C}\right)$ & $\mathrm{T}_{\mathrm{o}}\left({ }^{\circ} \mathrm{C}\right)$ & $\mathrm{T}_{\mathrm{e}}\left({ }^{\circ} \mathrm{C}\right)$ & $\mathbf{T}_{\mathrm{p}}\left({ }^{\circ} \mathrm{C}\right)$ & Heat $(\mathrm{J} / \mathrm{g})$ \\
\hline 5 & 123 & 153 & 143 & 153 & 187 & 179 & 120 & 188 & 179 & 249.0 \\
\hline 10 & 136 & 172 & 156 & 180 & 217 & 203 & 134 & 217 & 201 & 237.3 \\
\hline 15 & 141 & 179 & 161 & 187 & 222 & 208 & 139 & 228 & 207 & 248.9 \\
\hline 20 & 147 & 188 & 166 & 194 & 243 & 215 & 187 & 244 & 213 & 235.4 \\
\hline Mean & - & - & - & - & - & - & - & - & - & $240.5 \pm 7.4$ \\
\hline PGT & \multicolumn{3}{|c|}{ Peak 1} & \multicolumn{3}{|c|}{ Peak 2} & \multicolumn{4}{|c|}{ Peak 1 and Peak 2} \\
\hline Heating Rate $\left({ }^{\circ} \mathrm{C} \min ^{-1}\right)$ & To $\left({ }^{\circ} \mathrm{C}\right)$ & $\mathrm{Te}\left({ }^{\circ} \mathrm{C}\right)$ & $\operatorname{Tmax}\left({ }^{\circ} \mathrm{C}\right)$ & To $\left({ }^{\circ} \mathrm{C}\right)$ & $\operatorname{Te}\left({ }^{\circ} \mathrm{C}\right)$ & $\operatorname{Tmax}\left({ }^{\circ} \mathrm{C}\right)$ & $\mathrm{T}_{\mathrm{o}}\left({ }^{\circ} \mathrm{C}\right)$ & $\mathrm{T}_{\mathrm{e}}\left({ }^{\circ} \mathrm{C}\right)$ & $\mathrm{T}_{\max }\left({ }^{\circ} \mathrm{C}\right)$ & Heat $(\mathrm{J} / \mathrm{g})$ \\
\hline 5 & 139 & 164 & 151 & 169 & 192 & 186 & 139 & 166 & 152 & 509.2 \\
\hline 10 & 145 & 180 & 158 & 186 & 212 & 202 & 145 & 213 & 159 & 543.2 \\
\hline 15 & 150 & 188 & 163 & 193 & 217 & 207 & 148 & 221 & 163 & 552.0 \\
\hline 20 & 150 & 188 & 163 & 193 & 217 & 207 & 151 & 229 & 167 & 536.4 \\
\hline Mean & - & - & - & - & - & - & - & - & - & $535.2 \pm 18.5$ \\
\hline
\end{tabular}

$\left(\mathrm{T}_{\mathrm{o}}=\right.$ initial temperature, $\mathrm{T}_{\mathrm{e}}=$ final temperature and $\mathrm{T}_{\mathrm{p}}=$ maximum temperature peak $)$ 

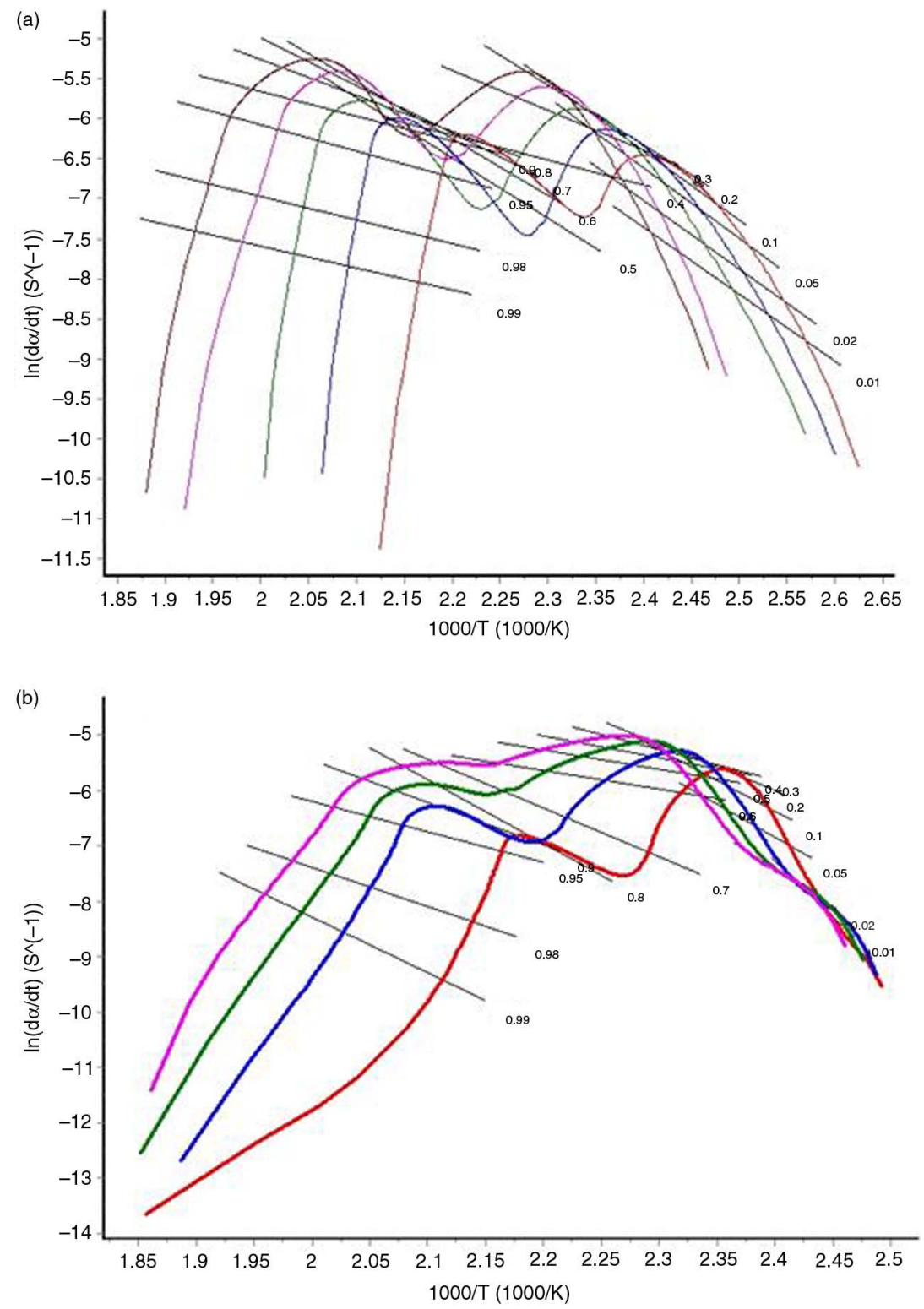

Figure 4. Isoconversional Friedman results for: (a) PGS and (b) PGT samples.

of activation energy were 61.1 and $110.3 \mathrm{KJ} / \mathrm{mol}$ for PGS and PGT, respectively.

Secondly, FWO method is an integrated method, which is also independent of the degradation mechanism. Eq. [7] was used and the activation energy of the PGS and PGT was obtained from plot $\log (\beta)$ against $1 / T$ at a fixed conversion with the slope such a line being 1.052E/R (Figure 5).

The values of activation energy of PGS and PGT are summarized in Table 5 and 6 , respectively. The means valued of activation energy were $62.4 \mathrm{KJ} / \mathrm{mol}$ for PGS and $107 \mathrm{KJ} / \mathrm{mol}$ for PGT.

Finally, ASTM E698 method based on the assumption that the maximum of the DSC curves of a reaction is reached at the same conversion degree independent of the heating rate. The activation energy was obtained from plot of $\log (\beta)$ against $1 / T$ with the slope of such a line being $E / R$. The values of the obtained activation energy of the both PG samples are summarized in the Table 5 and 6 . The values of activation energy were 67.9 and $128.4 \mathrm{KJ} / \mathrm{mol}$, for PGS and PGT, respectively.

Table 7 shows activation energy calculated by Coats-Redfern method for PGS and PGT at constant heating rate of $10 \mathrm{~K} / \mathrm{min}$. It was found that thermal dehydration mechanism of PGS is likely to be of first-order F1 type, because this mechanism presents the activation energy $(62.6 \mathrm{~kJ} / \mathrm{mol})$ similar to the value obtained by FR isoconversional method $(62.4 \mathrm{~kJ} / \mathrm{mol})$. It is clearly shows that the 
TABLE 5. Activation energies of PGS obtained by FWO, FR and EASTM E698 methods

\begin{tabular}{|c|c|c|c|c|c|c|}
\hline \multicolumn{2}{|c|}{ FWO } & \multicolumn{2}{|l|}{ FR } & \multicolumn{3}{|c|}{ ASTM E698 } \\
\hline$\alpha$ & $\mathrm{E}(\mathrm{kJ} / \mathrm{mol})$ & $\alpha$ & $\mathrm{E}(\mathrm{kJ} / \mathrm{mol})$ & $\begin{array}{c}\text { Heating } \\
\text { Rate }\left({ }^{\circ} \mathrm{C} / \mathrm{min}\right)\end{array}$ & $\begin{array}{c}\text { Temp. } \\
\text { Max. }\left({ }^{\circ} \mathrm{C}\right)\end{array}$ & $\begin{array}{c}1000 / \mathrm{T} \\
(1000 / \mathrm{K})\end{array}$ \\
\hline 0.01 & 67.4 & 0.01 & 70.2 & 5 & 453.8 & 2.20 \\
\hline 0.02 & 68.1 & 0.02 & 71.0 & 10 & 471.3 & 2.13 \\
\hline 0.05 & 68.6 & 0.05 & 72.8 & 15 & 480.8 & 2.08 \\
\hline 0.1 & 69.7 & 0.1 & 72.1 & 20 & 488.0 & 2.05 \\
\hline 0.2 & 68.8 & 0.2 & 65.7 & $\mathrm{E}(\mathrm{kJ} / \mathrm{mol})$ & & \\
\hline 0.3 & 67.2 & 0.3 & 63.2 & & & \\
\hline 0.4 & 60.4 & 0.4 & 64.5 & & & \\
\hline 0.5 & 59.7 & 0.5 & 62.2 & & & \\
\hline 0.6 & 58.5 & 0.6 & 60.7 & & & \\
\hline 0.7 & 58.6 & 0.7 & 59.6 & & & \\
\hline 0.8 & 57.0 & 0.8 & 57.4 & & & \\
\hline 0.9 & 55.4 & 0.9 & 55.7 & & & \\
\hline 0.95 & 53.8 & 0.95 & 53.1 & & & \\
\hline 0.98 & 52.1 & 0.98 & 54.5 & & & \\
\hline 0.99 & 51.0 & 0.99 & 53.1 & & & \\
\hline Mean & 61.1 & Mean & 62.4 & & & \\
\hline Standard deviation & 6.6 & Standard deviation & 6.9 & & & \\
\hline
\end{tabular}

TABLE 6. Activation energies of PGT obtained by FWO, FR and EASTM E698 methods

\begin{tabular}{|c|c|c|c|c|c|c|}
\hline \multicolumn{2}{|c|}{ FWO } & \multicolumn{2}{|l|}{ FR } & \multicolumn{3}{|c|}{ ASTM E698 } \\
\hline$\alpha$ & $\mathrm{E}(\mathrm{kJ} / \mathrm{mol})$ & $\alpha$ & $\mathrm{E}(\mathrm{kJ} / \mathrm{mol})$ & $\begin{array}{l}\text { Heating Rate } \\
\left({ }^{\circ} \mathrm{C} / \mathrm{min}\right)\end{array}$ & $\begin{array}{c}\text { Temp. Max. } \\
\left({ }^{\circ} \mathrm{C}\right)\end{array}$ & $\begin{array}{c}1000 / \mathrm{T} \\
(1000 / \mathrm{K})\end{array}$ \\
\hline 0.01 & 130.1 & 0.01 & 131.5 & 5 & 423.81 & 2.3595 \\
\hline 0.02 & 127.7 & 0.02 & 113.0 & 10 & 430.78 & 2.3214 \\
\hline 0.05 & 125.2 & 0.05 & 110.6 & 15 & 434.31 & 2.3025 \\
\hline 0.1 & 123.5 & 0.1 & 110.0 & 20 & 437.66 & 2.2849 \\
\hline 0.2 & 120.2 & 0.2 & 113.0 & $\mathrm{E}(\mathrm{kJ} / \mathrm{mol})$ & 128 & \\
\hline 0.3 & 110.8 & 0.3 & 110.9 & & & \\
\hline 0.4 & 105.5 & 0.4 & 105.5 & & & \\
\hline 0.5 & 99.0 & 0.5 & 100.8 & & & \\
\hline 0.6 & 96.4 & 0.6 & 97.7 & & & \\
\hline 0.7 & 93.2 & 0.7 & 99.3 & & & \\
\hline 0.8 & 90.8 & 0.8 & 99.8 & & & \\
\hline 0.9 & 89.5 & 0.9 & 99.1 & & & \\
\hline 0.99 & 89.0 & 0.99 & 99.7 & & & \\
\hline Mean & 110.3 & Mean & 107.0 & & & \\
\hline Standard deviation & 15.8 & Standard deviation & 9.4 & & & \\
\hline
\end{tabular}

mechanism for PGT dehydration is proposed to be three-dimensional diffusion (D3) type. The activation energy of this mechanism was around $117.9 \mathrm{~kJ} / \mathrm{mol}$, which was similar to activation energy obtained by FR isoconversional method (107 kJ/mol).

The values of the activation energy are similar when calculated using the FR and FWO methods, while the ones obtained by the ASTM method are higher than the previous ones. Indeed, the ASTM method, using the results of TG curves, provides good kinetics results. However and in this case, it seems that using the results of the DSC curves, the results are very different to the ones obtained by the other calculation methods. 

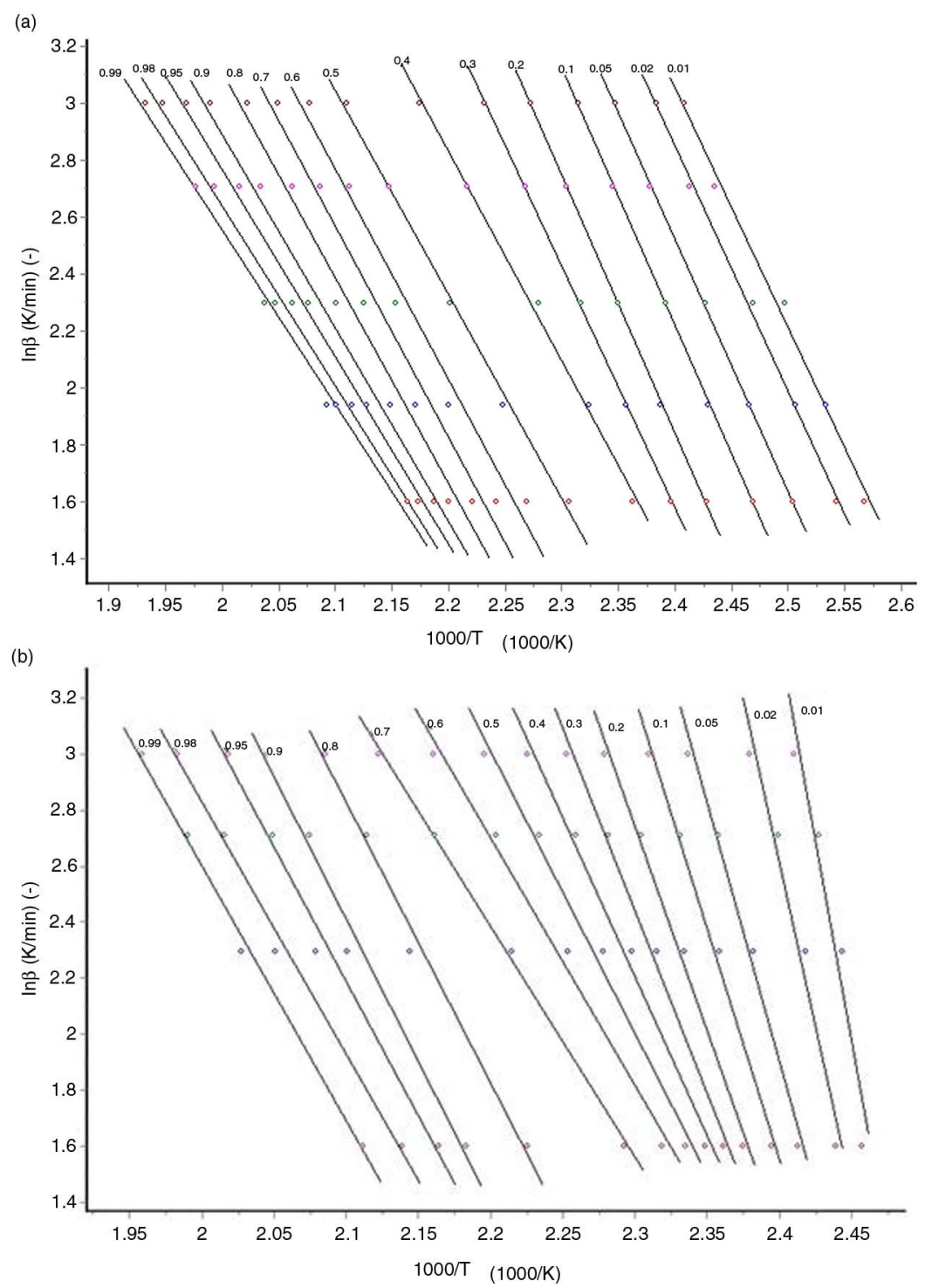

FIGURE 5. FWO plots of: (a) PGS and (b) PGT samples.

Thus the activation energy of the PG dehydration reaction, calculated from the global reaction (setp 1 and setp 2) varies depending on the calculation methods used between 61 and $63 \mathrm{~kJ} / \mathrm{mol}$ for PGS sample and $107-118 \mathrm{~kJ} / \mathrm{mol}$ for PGT samples.

The kinetics equations for PG dehydration is as follows [15], [16]:

$$
\frac{d \alpha}{d t}=1.01 \times 10^{0.5} e^{-62.61 \times 10^{3} / R T}(1-\alpha) \text { for PGS }
$$

$$
\frac{d \alpha}{d t}=5.46 \times 10^{10} e^{-117.9 \times 10^{3} / R T} \frac{3(1-\alpha)^{2 / 3}}{2\left(1-(1-\alpha)^{1 / 3}\right)} \text { for PGT }
$$

Figure 6 shows the changes in the activation energy calculated by means of the Friedman method, according to the conversion degree for the global dehydration reaction of each studied PG sample.

It is clearly shows that the dehydration reaction takes place via a clearly two differentiated steps.

For PGS sample, the first step of the reaction occurs for $0.02 \leq \alpha \leq 0.53$, with an average value of activation energy of $68 \pm 6 \mathrm{~kJ} / \mathrm{mol}$ and the second step for $0.53 \leq \alpha \leq 0.99$ with an average value of activation energy of $51 \pm 2 \mathrm{~kJ} / \mathrm{mol}$.

For PGT sample, the first step of the reaction occurs for $0.02 \leq \alpha \leq 0.74$, with an average value of activation energy of $110 \pm 6 \mathrm{~kJ} / \mathrm{mol}$ and the second step for $0.74 \leq \alpha \leq 0.99$ with an average value of activation energy of $77 \pm 2 \mathrm{~kJ} / \mathrm{mol}$. In both PG samples, the first step of the reaction, corresponding to the formation of the hemihydrate, contributes most to activation energy of the global reaction of the 
TABLE 7. Activation energies, conversion factor and order of reaction of PGS and PGT obtained by Coats-Redfern method

\begin{tabular}{|c|c|c|c|c|c|c|}
\hline \multirow[b]{2}{*}{ Model } & \multicolumn{3}{|c|}{ PGS } & \multicolumn{3}{|c|}{ PGT } \\
\hline & $A\left(s^{-1}\right)$ & $\mathrm{E}(\mathrm{kJ} / \mathrm{mol})$ & n & $A\left(s^{-1}\right)$ & E (kJ/mol) & $\mathbf{n}$ \\
\hline Auto catalytic & $1.80 \times 10$ & 39.5 & 0.683 & $3.01 \times 10^{3}$ & 45.1 & 1.11 \\
\hline A 1.5 & $2.49 \times 10^{2}$ & 41.1 & 1.5 & $6.58 \times 10^{1}$ & 33.8 & 1.5 \\
\hline A2 & $1.14 \times 10^{1}$ & 30.3 & 2 & $9.82 \times 10^{-1}$ & 19.1 & 2 \\
\hline An & $3.20 \times 10^{2}$ & 41.9 & 1.47 & $8.79 \times 10^{1}$ & 34.9 & 1.47 \\
\hline D1 & $1.24 \times 10^{5}$ & 68.2 & - & $9.24 \times 10^{3}$ & 55.9 & - \\
\hline D2 & $8.14 \times 106$ & 84.8 & - & $9.02 \times 10^{6}$ & 82.2 & - \\
\hline D3 & $1.04 \times 10^{9}$ & 106.6 & - & $5.64 \times 10^{10}$ & 117.9 & - \\
\hline D4 & $1.67 \times 10^{7}$ & 92.4 & - & $7.38 \times 10^{7}$ & 94.7 & - \\
\hline $\mathrm{F} 1$ & $1.01 \times 10^{5}$ & 62.6 & 1 & $2.49 \times 10^{5}$ & 63.3 & 1 \\
\hline $\mathrm{F} 2$ & $2.44 \times 10^{10}$ & 105.0 & 2 & $1.11 \times 10^{14}$ & 132.6 & 2 \\
\hline F3 & $5.91 \times 10^{15}$ & 147.5 & 3 & $4.97 \times 10^{22}$ & 202.0 & 3 \\
\hline Fn & $1.55 \times 10^{3}$ & 48.3 & 0.663 & $1.4 \times 10^{6}$ & 69.3 & 1.09 \\
\hline $\mathrm{P} 1$ & $4.15 \times 10^{-1}$ & 20.2 & 1 & $5.59 \times 10^{-4}$ & -61.0 & 1 \\
\hline P2 & $5.36 \times 10^{-4}$ & -3.9 & 2 & $9.71 \times 10^{-8}$ & -37.1 & 2 \\
\hline P3 & $4.9 \times 105$ & -11.9 & 3 & $4.55 \times 10^{-9}$ & -47.5 & 3 \\
\hline P4 & $1.36 \times 10^{-5}$ & -15.9 & 4 & $9.06 \times 10^{-10}$ & -52.6 & 4 \\
\hline Pn & $1.15 \times 10^{-1}$ & 15.4 & 1.11 & $9.32 \times 10^{-7}$ & -29.2 & 1.59 \\
\hline R2 & $1.02 \times 10^{2}$ & 41.4 & 2 & 5.9 & 28.6 & 2 \\
\hline R3 & $5.38 \times 10^{2}$ & 48.5 & 3 & $1.09 \times 10^{2}$ & 40.1 & 3 \\
\hline $\mathrm{Rn}$ & $5.21 \times 10^{2}$ & 48.3 & 2.97 & $-1.21 \times 10^{5}$ & 69.3 & 1.5 \\
\hline
\end{tabular}

dehydration than the second step, transformation of hemihydrate to anhydrate.

In the literature, there is a number of studies on kinetics dehydration of gypsum $(25,27,43-49)$. In general, all the studies of the $\mathrm{CaSO}_{4} 2 \mathrm{H}_{2} \mathrm{O}$ dehydration through DTA or DTG show the presence of two endothermic peaks. However, the dehydration temperatures have been quite varied. This difference

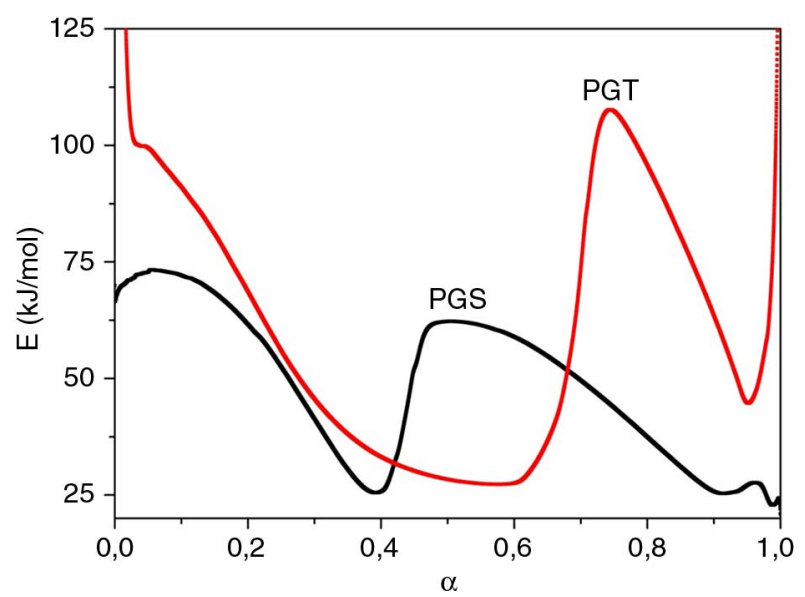

FIGURE 6. The activation energy calculated by means of the Friedman method, according to the conversion degree for the global dehydration reaction of each PG sample. might be explained by the influence of nature as well as by the different origins of the samples. Although many studies about the decomposition of gypsum have been reported, we have not noticed any work about the kinetics of thermal dehydration of PG. The mechanisms involved in the dehydration of the PG are different from that of the natural gypsum, and some impurities in PG could influence the dehydration mechanism.

Comparing the experimental values of the activation energy obtained in this work to others values reported in the literature, we noted that the PGT is composed exclusively of gypsum and presents an activation energy comparable to that obtained by Elbeyli et al. (2004) (50) $(95-114 \mathrm{~kJ} / \mathrm{mol})$ in their study the kinetic decomposition in non-isothermal conditions of a borogypsum composed by $\mathrm{CaSO}_{4}$ $2 \mathrm{H}_{2} \mathrm{O}$. The values obtained in this work are also within the range of the values done by Lou et al. (2001) (48) when they study the kinetic dehydration of the flue gas desulphurisation phosphogypusm in variable conditions of partial water pressure (79-136 kJ/mol). Furthermore, Kontogeorgos and Founti (2012) (51) reported that the activation energy for the transformation of the calcium sulfate dihydrate into soluble calcium sulfate anhydrite III can be assumed to take place in three stages: nucleation $(\alpha<0.1$ and $\mathrm{E} \approx 144 \mathrm{~kJ} / \mathrm{mol})$, nuclei growth 
$(0.1<\alpha<0.7$ and $E \approx 100 \mathrm{~kJ} / \mathrm{mol})$ and water molecule diffusion $(\alpha>0.7$ and $E \approx 83 \mathrm{~kJ} / \mathrm{mol})$.

The differences between these values and the values found in this paper could be attributed to the different origin of the raw material and/or the impurities.

\section{CONCLUSIONS}

Therefore the obtained results allow to know the phosphogypsum dehydration temperature. This allows to obtain an adequate desing of indrustrial milling system for the cement production.

Before the use of phosphogypsum in the cement production as setting regulator is necessary to do a thermal study to avoid the false setting by the production of hemihydrate and anhydrate phases.

The mineralogical composition of Spanish phosphogypsum PGS was approximately of $64 \%$ of $\mathrm{CaSO}_{4} \cdot 2 \mathrm{H}_{2} \mathrm{O} ; 33 \% \mathrm{CaSO}_{4} \cdot 0.5 \mathrm{H}_{2} \mathrm{O}$ and $3 \%$ of $\mathrm{CaSO}_{4}$. The Tunisia phosphogypsum, PGT is only composed by a $94 \%$ of $\mathrm{CaSO}_{4} \cdot 2 \mathrm{H}_{2} \mathrm{O}$.

The thermal studies, DTG and DTA, show difference in the dehydration temperature, due to the difference in the origin sample, chemical composition. The dehydration of the PGS sample started at lowest temperature $\left(133^{\circ} \mathrm{C}\right)$ than PGT sample $\left(143^{\circ} \mathrm{C}\right)$.

The kinetics of the thermal dehydration of two PG sources (Spain and Tunisia) was accurately determined through a series of experiments at four heating rates $(5,10,15$ and $20 \mathrm{~K} / \mathrm{min})$.

The activation energy was calculated by the isoconversional methods (Friedman, Flyn-Wall-Ozawa and ASTM E986) without previous assumption regarding the conversion fulfilled by the reaction.

Finally, Coats-Redfern method were successfully utilized to predict the reaction mechanism of thermal dehydration of $\mathrm{PG}$. The dehydration reaction model of PGS can be described by "first-order" model, whereas that of PGT by "three-dimensional diffusion" model.

\section{ACKNOWLEDGEMENTS}

The authors are grateful to the Spanish National R\&D\&I Plan and FEDER (Project CTQ200802012/ PPQ) for the financial support of this study. Dr. I. García-Díaz expresses her gratitude to the Ministry of Economy and Competitiveness for their Postdoctoral Junior Grants (Ref. FPDI-2013-16391) contracts cofinanced by the European Social Fund.

\section{REFERENCES}

1. Pérez-López, R.; Nieto, J.M.; López-Coto, I; Aguado, J.L.; Bolivar, J.P.; Santisteban, M. (2010). Dynamics of contaminants in phophogypsum or the fertilizer industry of Huelva (SW Spain): From phosphate rock ore to the environment. Appl. Geochem., 25 [5], 705-715. http://dx.doi. org/10.1016/j.apgeochem.2010.02.003.
2. Rutherford, P.M.; Dudas, M.J.; Samek, R.A. (1994) Environmental impacts of phosphogypsum. Sci. Tot. Environ. 149 [1, 2], 1-38. http://dx.doi.org/10.1016/0048-9697(94) 90002-7.

3. Tayibi, H.; Choura, M.; López, F.A.; Alguacil, F.J.; LópezDelgado, A. (2009) Environmental impact and management of phosphogypsum. J. Environ. Manag. 90 [8], 2377-2386. http://dx.doi.org/10.1016/j.jenvman.2009.03.007.

4. Kuryatnyk T; Angulski da luz, C.; Ambroise, J.; Pera, J. (2008) Valorization of phosphogypsum as hydraulic binder. J. Hazard. Mat. 160 [2-3], 681-687. http://dx.doi. org/10.1016/j.jhazmat.2008.03.014

5. Mas, J.L.; San Miguel, E.G.; Bolívar, J.P.; Vaca, F.; PérezMoreno, J.P. (2006) An assay on the effect of preliminary restoration tasks applied to a large TENORM wastes disposal in the South-West of Spain. Sci Tot. Environ. 364 [1-3], 55-66. http://dx.doi.org/10.1016/j.scitotenv.2005.11.006.

6. Papastefanou, C.; Stoulos, S.; Ioannidou, A.; Manolopoulou, M. (2006) The application of phosphogypsum in agriculture and the radiological impact. J. Environ. Radioact. 89 [2], 188-189. http://dx.doi.org/10.1016/j.jenvrad.2006. 05.005 .

7. Garrido, F.; Illera, V.; García-Gonzalez, M.T. (2005) Effect of the addition of gypsum and lime rich industrial byproducts on $\mathrm{Cd}, \mathrm{Cu}$ and $\mathrm{Pb}$ availability and leachability in metal-spiked acid soils. Appl. Geochem. 20 [2], 397-408. http://dx.doi.org/10.1016/j.apgeochem.2004.08.001.

8. Abril, J.M.; García-Tenorio, R.; Periá-ez, R.; Enamorado, S.M.; Andreu, L.; Delgado, A. (2009) Occupational dosimetric assessment (inhalation pathway) from the application of phosphogypsum in agriculture in South West Spain. J. Environ. Radioact. 100, 29-34. http://dx.doi.org/10.1016/j. jenvrad.2008.09.006

9. Potgieter, J.H.; Potgieter, S.S.; McCrindle, R.I.; Strydom, C.A. (2003) An investigation into the effect of various chemical and physical treatments of a South African phosphogypsum to render a suitable as a set retarder for cement. Cem. Concr. Res. 33 [8], 1223-1227. http://dx.doi. org/10.1016/S0008-8846(03)00036-X

10. Altun, I.A.; Sert, Y. (2004) Utilization of weathered phosphogypsum as set retarder in Portland cement. Cem. Concr. Res. 34, 677-680. http://dx.doi.org/10.1016/j.cemconres. 2003.10.017.

11. Garg, M.; Jain, N.; Singh, M. (2009) Development of alfa plaster from phosphogypsum for cementitious materials. Constr. Build. Mater. 23 [10], 3138-3143. http://dx.doi.org/ 10.1016/j.conbuildmat.2009.06.024.

12. Garg, M.; Jain, N. (2010) Waste gypsum from intermediate dye industries for production of building materials. Constr. Build. Mater. 24 [9], 1632-1637. http://dx.doi.org/10.1016/j. conbuildmat.2010.02.029.

13. Kacimi, L.; Simon-Masseron, A.; Ghomari, A.; Derriche, Z. (2006) Reduction of clinkerization temperature by using phosphogypsum. J. Hazard. Mat. 137 [1], 129-13. http:// dx.doi.org/10.1016/j.jhazmat.2005.12.053.

14. Elkhadiri, I.; Diouri, A.; Boukhari, A.; Puertas, F.; Vázquez, T. (2003) Obtaining a sulfoaluminate belite cement by industrial waste. Mater. Construcc. 53 [270], 57-69. http://dx.doi. org/10.3989/mc.2003.v53.i270.278.

15. El-Alfi, E.-S.A. (2004) Sulfoaluminate-belite cement from limestone, phosphogypsum and other waste product. Stud. Technol. 12, 928-935.

16. Karagöz Öztürk, A.; Oguz, H. (2004) The formation of alite phase by using phosphogypsum and oil shale. Cem. Concr. Res. 34 [11], 2079-2082. http://dx.doi.org/10.1016/j. cemconres.2004.03.013

17. Taher, M.A. (2007) Influence of thermally treated phosphogypsum on the properties of Portland slag cement. Resour. Conservat. Recycl. 52 [1], 28-38. http://dx.doi.org/10.1016/j. resconrec.2007.01.008.

18. Coruh, S.; Ergun, N.O. (2010) Use fly ash, phosphogypsum and red mud as a linear material for the disposal of hazardous zinc leach residue waste. J. Hazard. Mat. 173 [1-3], 468-473. http://dx.doi.org/10.1016/j.jhazmat.2009.08.108.

19. Shen, W.; Zhou, M.; Ma, W.; Hu, J.; Cai, Z. (2009) Investigation on the application of steel slag-fly ash-phosphogypsum 
solidified material as road base material. J. Hazard. Mat. 164 [1], 99-104. http://dx.doi.org/10.1016/j.jhazmat.2008.07.125.

20. Yang, J.; Liu, W.; Zhang, L.; Xiao, B. (2009) Preparation of load-bearing building materials from autoclaved phosphogypsum. Constr. Build. Mat. 23 [2], 687-693. http://dx.doi. org/10.1016/j.conbuildmat.2008.02.011.

21. Lea's, (1998) P.C. Hewlett (Ed.), Lea's Chemistry of Cement and Concrete 4th ed. Arnold, London, 83-85.

22. Cruz, I.; Vázquez, T.; Fernandez-Pe-a, O. (1983) Sulfatos en el cemento Portland y su incidencia sobre el falso fraguado: Estado actual del conocimiento. Mater. Construcc. 192, 43-55. http://dx.doi.org/10.3989/mc.1983.v33.i192.967.

23. Taylor H.F.W.; Cement Chemistry, 2nd ed., Thomas Telford Publishing, (1997), 84. http://dx.doi.org/10.1680/cc.25929.

24. Mantell, D.G. (Ed.), PPC: The Manufacure, Properites and Applicatoins of Portland Cements, Cement Additives and Blended Cements 1991, PPC Johannesburg, pp. 13 and 14.

25. Strydom, C.A.; Hudson-Lamb, D.L.; Potgieter, J.H.; Dagg, E. (1995) The thermal dehydration of synthetic gypsum. Thermochim. Acta. 269/270, 631-638. http://dx.doi. org/10.1016/0040-6031(95)02521-9.

26. Papageorgiou, A.; Tzouvalas, G.; Tsimas, S.; (2005) Use of inorganic setting retarders in cement industry. Cem. Concr. Compos., 27 [2], 183-189. http://dx.doi.org/10.1016/j. cemconcomp.2004.02.005.

27. Charola, A.E.; Puhringer, J.; Steiger, M. (2007) Gypsum: a review of its role in the deterioration of building materials. Environ. Geol. 52 [2], 339-52. http://dx.doi.org/10.1007/ s00254-006-0566-9.

28. Ballirano, P.; Melis, E. (2009) Thermal behaviour and kinetics of dehydration of gypsum in air from in situ real-time laboratory parallel beam X-ray powder diffraction. Phys. Chem. Mineral. 36 [7], 391-402. http://dx.doi.org/10.1007/ s00269-008-0285-8.

29. Friedman, H. (1964) Kinetics of thermal degradation of char-forming plastics from thermogravimetry. Application to a phenolic plastic. J Polym Sci Part C. 6,183-195. http:// dx.doi.org/10.1002/polc.5070060121.

30. Flynn, J.H.; Wall, L.A. (1966) A quick, direct method for the determination of activation energy from thermogravimetric data. Polym. Lett. 4 [5],323-328. http://dx.doi.org/10.1002/ pol.1966.110040504.

31. Ozawa, T. (1965) A new method of analyzing thermogravimetric data. Bull. Chem. Soc. Jpn. 38, 1881-1886. http:// dx.doi.org/10.1246/bcsj.38.1881.

32. Doyle, C.D. (1961) Kinetic analysis of thermogravimetric data. J. Appl. Polym. Sci. 5 [15], 285-292. http://dx.doi. org/10.1002/app.1961.070051506.

33. Standard Test Method for Arrhenius Kinetic Constants for Thermally Unstable Materials Using Differential Scanning Calorimetry and the Flynn/Wall/Ozawa Method, American Society for Testing and Materials (ASTM) E698, 2011.

34. Coats, A.W.; Redfern, J.P. (1964) Kinetic parameters from thermogravimetric data. Nature. 201, 68-6. http://dx.doi.org/ $10.1038 / 201068 \mathrm{a} 0$.

35. Ma,L.; Ning,P.;Zheng, S.; Nui, X.;Zhang, W.; Du, Y.(2010) Reaction mechanism and kinetic analysis of the decomposition of phosphogypsum via solid-state reaction. Ind. Ing. Chem. Res. 49 [8], 3597-3602. http://dx.doi.org/10.1021/ ie901950y.

36. Strydom, C.A.; Potgieter, J.H. (1999) Dehydration behaviour of a natural gypsum and phosphogypsum during milling. Thermochim. Acta. 332 [1], 89-96. http://dx.doi.org/10.1016/ S0040-6031(99)00083-0.
37. López, F.A.; Gázquez, M.; Alguacil, F.J.; Bolívar, J.P.; García-Díaz, I.; López-Coto, I. (2011) Microencapsulation of phosphogypsum into a sulfur polymer matrix: Physicochemical and radiological characterization. J. Hazard. Mat. 192 [1], 234-245. http://dx.doi.org/10.1016/j.jhazmat.2011. 05.010 .

38. Cárdenas-Escudero, C.; Morales-Flórez, V.; Pérez-López, R; Santos, A; Esquivias, L. (2011) Procedure to use phosphogypsum industrial waste for mineral $\mathrm{CO}_{2}$ sequestration. J. Hazard. Mat. 196, 431-435. http://dx.doi.org/10.1016/j. jhazmat.2011.09.039.

39. Sebbahi, S.; Lemine, M.; Sahban, F.; Aride, J.; Benarafa, L.; Belkbir, L. (1997) Thermal behaviour of Moroccan phosphogypsum. Thermochim. Acta. 302 [1-2], 69-75. http:// dx.doi.org/10.1016/s0040-6031(97)00159-7.

40. Manzello, S.L.; Gann, R.G.; Kukuck, S.R.; Prasad, K., Jones, W. (2007) Fire performance of a non-load-bearing steel stud gypsum board wall assembly: experiments and modeling. Fire and Mat. 31, 297-310. http://dx.doi.org/ 10.1002/fam.939.

41. Deutsch, Y.; Nathan, Y.; Sarig, S. (1994) Thermogravimetric evaluation of the kinetics of the gypsum-hemihydratesoluble anhydrite transition. J. Therm. Anal. Calorim. 42 [1], 159-174. http://dx.doi.org/10.1007/bf02546998.

42. Putnis, A.; Winkler, B.; Fernandez-Diaz, L. (1990) In situ IR spectroscopic and thermogravimetric study of the dehydration of gypsum. Mineral Mag. 54, 123-138. http://dx.doi. org/10.1180/minmag.1990.054.374.14.

43. Dos Santos, V.A.; Pereira, J.A.F.R.; Dantas, C.C. (1997) Kinetics of thermal dehydration of gypsum ore for obtaining beta hemihydrate in a fluidized bed. Bull Soc. Chim. Belg. 6, 253-60.

44. Chang, H.; Huang, P.J.; Hou, S.C. (1999) Application of thermo-Raman spectroscopy to study dehydration of

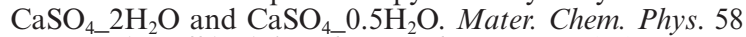
[1], 12-9. http://dx.doi.org/10.1016/S0254-0584(98)00239-9.

45. Prasad, P.S.R.; Chaitanya, V.K.; Prasad, K.S.; Rao, D.N (2005) Direct formation of the c-CaSO 4 phase in dehydration process of gypsum: in situ FTIR study. Am. Mineral. 90 [4], 672-678. http://dx.doi.org/10.2138/am.2005.1742.

46. Ball, M.; Norwood, L.S. (1969) Studies in the system calcium sulphate water. Part I. Kinetics of dehydration of calcium sulphate dehydrate. J. Chem. Soc. A. 1633-1637. http://dx.doi.org/10.1039/j19690001633.

47. Badens, E.; Llewellyn, P.; Fulconis, J.M.; Jourdan Veesler, C.S.; Boistelle, R. (1998) Study of gypsum dehydration by controlled transformation rate thermal analysis (CRTA). $J$. Solid State Chem. 139 [1], 37-44. http://dx.doi.org/10.1006/ jssc.1998.7797.

48. Lou, W. Guan, B ; Wu, Z (2011) Dehydration behaviour of FGD gypsum by simultaneous TG and DSC analysis. J. Therm. Anal. Calorim. 104 [2], 661-669. http://dx.doi. org/10.1007/s10973-010-1100-6.

49. Hudson-Lamb, D.L.; Strydom, C.A.; Potgieter, J.H. (1996) The thermal dehydration of natural gypsum and pure calcium sulphate dehydrate (gypsum). Thermochim. Acta. 282/283 [SPEC. ISS.], 483-492. http://dx.doi.org/10.1016/ 0040-6031(95)02819-6.

50. Elbeyli, I.K.; Piskin, S. (2004) Kinetic study of the thermal dehydration of phosphogypsum. J. Hazard. Mater. 116 [1-2], 111-117. http://dx.doi.org/10.1016/j.jhazmat.2004.08.024.

51. Kontogeorgos, D.A.; Founti, M.A. (2012) Gypsum board reaction kinetics at elevated temperatures. Thermochim. Acta. 529 [10], 6-13. http://dx.doi.org/10.1016/j.tca.2011.11.014. 